\title{
The effect of self-regulated learning strategies on the primary school students' independent learning skill
}

\author{
Sukowati Sukowati *, E. Kus Eddy Sartono, Gunarti Ika Pradewi \\ Universitas Negeri Yogyakarta. Jalan Colombo No. 1, Yogyakarta, 55281, Indonesia \\ * Corresponding Author. E-mail: sukowati.2018@student.uny.ac.id
}

Received: 2 March 2020; Revised: 1 April 2020; Accepted: 7 April 2020

\begin{abstract}
Students have Self-Regulated Learning (SRL) which can motivate themselves to arrange personal goals, plan strategies done to achieve the goal, until to evaluate the behaviors. Besides that, students can be more responsible to themselves so that the learning independence of students can be formed. This research aimed to investigate the level of SRL and learning independence of elementary school students, and to investigate the influence of SRL towards the learning independence of elementary school students. This research used a quantitative approach with the comparative research design. The population in this research was 387 students with the sample used was 194 students taken randomly using Slovin's formula. The instrument used in this research consisted of 24 questions by using 4-point Likert Scale. The data collection technique was used by comparing SRL of students. The data analysis was conducted by SPSS version 24. The finding of the research showed that SLR and learning independence of elementary school students was on the category medium and has a tcount of 8,516. In addition, the F-test result obtained was 240, 783. Therefore, it can be concluded that there is a significant influence between SRL and the learning independence of elementary school students. The futher reasearch must be based on previous studies. The influence of SRL on student independence and the factors that influence needed to described more comperhensive.
\end{abstract}

Keywords: self-regulated learning (SRL); learning independence; elementary school students

How to Cite: Sukowati, S., Sartono, E. K. E., \& Pradewi, G. I. (2020). The effect of selfregulated learning strategies on the primary school students' independent learning skill. Psychology, Evaluation, and Technology in Educational Research, 2(2), 81-89. doi:http://dx.doi.org/10.33292/petier.v2i2.44

\section{INTRODUCTION}

Students with learning independence will be more active in the learning activity. Therefore, they have initiative to find new experience (Mudjiman, 2007) through an independent learning activity without the aid of friends or teachers (Davis et al., 2016; Maldonado-Mahauad et al., 2018; Wong et al., 2019). A learning independence is assigned by the internal motive in the form of willingness and awareness which encourages students to conduct some learning activities without any force from other parties (Deci \& Ryan, 2008; Ryan \& Deci, 2017). Therefore, learning independence is essential to be developed in order to make sure that students are responsible in managing and developing their study ability consciously (Rusman, 2011). Students who have learning independence will not depend on teachers in achieving new knowledge and information (Zimmerman, 1990; Zimmerman \& MartinezPons, 1990). The high curiosity motivates students to explore a new experience.

Learning independence is also related to the ability in managing and organizing lesson plan, time, even their own learning purpose (Zheng et al., 2020; Zimmerman, 2008). Students learn based on their initiative so they can control themselves. This process is known as self -regulation. The ability of students in managing themselves especially in the learning process is an essential process (Acar \& Aktamış, 2010; Aktamış \& Acar, 2010; Ariani, 2016).

Self-regulation is a process which manages mind, behavior, and emotion in order to achieve the goal (McClelland \& Cameron, 2012; Schunk, 2012). If the goal is related to the learning process, so 
the self-regulation is a kind of regulation in the learning or self-regulated learning (SRL). Self-regulation in the learning is a strategy used by students to manage cognition and knowledge (Azevedo et al., 2005). Students who have SLR are able to recognize themselves well (Jakešová et al., 2016), so they know what is needed to obtain the best learning outcome, such as determine learning style, measure their capacity, solve difficult problem, explore their interest and talent, and to be able to utilize their potency (Butler, 1998; Vermunt \& Vermetten, 2004).

SLR in learning consists of three aspects namely metacognition, motivation, and behavior (Bandura, 1986; Boekaerts, 1997; Panadero, 2017). In the perspective of SLR, a student with SLR ability will be able to plan, organize, instruct, monitor, and evaluate himself in the learning process (Gavora et al., 2015). Therefore, in the perspective of motivation, a student will feel more competent and have more self-efficacies and independences (Labuhn et al., 2008; Peeters et al., 2016; Schunk, 2005; Vandevelde et al., 2013).

In another side related to the aspect of behaviour, student will be able to select, compose, and manage the environment to create a good learning environment (Artino \& Jones, 2012; Stefanou et al., 2014). In the end, the components of SLR in learning will make them as active students who are independent in the learning process (Wong et al., 2019).

Besides that, SLR is not a characteristic of personality (Fonagy \& Target, 2002). SLR is developed by the support of people and environment (De Backer et al., 2015; Panadero \& Järvelä, 2015). In the school, SLR of students is slowly formed through the interaction with peer partner and teacher in an interaction inside or outside the class (Lai \& Hwang, 2016). The interaction with peer partner will motivate student to be more honest, able to work in team, be honest, fairly behave, and obey the rules. Whereas, the interaction with teacher will motivate students to politely behave, obey the rules, be independent, and communicative (Lai \& Hwang, 2016).

Some previous researches also find that SLR is essential to the students' learning independence (Ariani, 2016; Green et al., 2006; Kadhiravan, 2012). It occurs because students can manage themselves to achieve the needed knowledge without depending on other people (Van Laer \& Elen, 2019). The other research results also show that SLR gives the effective impact towards the students' learning independence in every learning process (Hong \& O'Neil, 2001).

Based on the description of the importance of SLR for students above, it is important to conduct a research regarding the effect of SLR towards the learning independence. Therefore, teacher as the party who is directly involved in the learning process can conduct some actions in order to develop SLR. It is expected to give more effects towards students' learning independence.

\section{METHOD}

This research uses a quantitative approach with the type of ex-post facto). Quantitative research is an educational research, where researchers decide what to study, compile specific questions, limit questions, collect measurable data from participants, analyze numbers using statistics, conduct impartial investigations, carried out in ways that are objective (Creswell, 2013). The subject of this research was students in grade IV of elementary schools in the district of Lendah, Kulon Progo, Yogyakarta with the population comprising 378 students. The sample in this research comprising 194 students taken by using random sampling technique. Samples in this study were 194 students taken using a random sampling technique which means that all members of the population have the same probability/opportunity to be selected as sample members) (Creswell, 2013). The design of the research as follow (Figure 1):
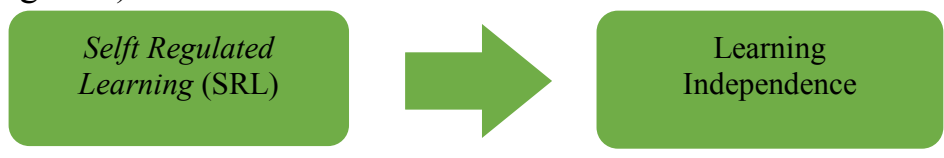

Figure 1. The influence of SLR towards learning independence

Data collection obtained by using research instruments made by researchers based on theory. Then validated to obtain the instrument validity. The Instrument of data collection consisted of 24 question items for SLR and 26 question items for learning independence. The instrument used Likert scale 4 point with scale 1 (very inappropriate) - 4 (very appropriate). A Likert scale is a set of items consisting of not only one item, but several items which are then averaged to produce an overall score 
(Creswell, 2012; Schreiber \& Asner-Self, 2010). This scale provides response options for questions assuming the same distance between options consisting of three, four, or more responses provided (Creswell, 2012).

The Data obtained were analyzed quantitatively using SPSS 24. SLR and students' learning independence in elementary school were categorized into three groups, namely high group, medium group, and low group (Arikunto, 2010). Therefore, the grouping of SLR is presented in the Table 1:

Table 1. Classification of SLR and Elementary school students' learning independence

\begin{tabular}{cc}
\hline Interval & Category \\
\hline $\mathrm{X}<(\mu-1,0 \sigma)$ & Low \\
$(\mu-1,0 \sigma) \leq \mathrm{X}<(\mu-1,0 \sigma)$ & Medium \\
$(\mu-1,0 \sigma) \leq \mathrm{X}$ & High \\
\hline
\end{tabular}

To investigate the effect of SLR towards the learning independence, it is used pre-requirement test such as normality test and linearity test. After the data was stated as normal and linear, then hypothesis test was conducted such as $t$ test, $F$ test, and determination coefficient test (R2).

Hypothesis to examine the influence of SLR towards the learning independence as follow:

$\mathrm{H}_{0}=$ there is no positive and significant effect between SLR and students' learning independence.

$\mathrm{H}_{1}=$ there is positive and significant effect between SLR and students' learning independence.

Therefore, it can be concluded that if the significance value is $<0.05$ so $\mathrm{H}_{0}$ is rejected. Meanwhile, if the significance value is $>0.05$ so $\mathrm{H}_{0}$ is accepted.

\section{RESULTS AND DISCUSSION}

\section{Results}

Self-Regulated Learning (SLR)

The data of SLR in this research were measured using psychological scale consisted of 24 question items with the score 1-4 for every item. The result of descriptive analysis consisted of mean (M), median (Me), mode (Mo), standard deviation, maximum score, minimum score, and variance.

Table 2. The Result of SLR Descriptive Analysis of Elementary School Students

\begin{tabular}{c|c}
\hline Mean & 75.74 \\
Median & 76.00 \\
Mode & 69 \\
Std. Deviation & 9.641 \\
Variance & 92.426 \\
Mininum & 44 \\
maximum & 96 \\
\hline
\end{tabular}

Based on the Table 2, it can be seen that the lowest score is 44; the highest score is 96; the variance is 92.426 , standard deviation is 9.614 ; mode is 69 ; median is 76.00 ; and mean is 75.74 . The tendency of average SLR score of students was found by categorizing ideal average score which supposed to be obtained. Therefore, it was obtained the maximum score 96 and the minimum score 44 .

Furthermore, the calculation of interval class was 8.5497 and rounded to 9 classes with the length of interval was 6 .

Table 3. The Distribution of SLR Frequency of Elementary School Students

\begin{tabular}{cccc}
\hline No. & Score Interval & Frequency & Percentage \\
\hline 1. & $44-49$ & 1 & $0.52 \%$ \\
2. & $50-55$ & 1 & $0.52 \%$ \\
3. & $56-61$ & 11 & $5.67 \%$ \\
4. & $62-67$ & 29 & $14.95 \%$ \\
5. & $68-73$ & 45 & $23.19 \%$ \\
6. & $74-79$ & 32 & $16.49 \%$ \\
7. & $80-85$ & 44 & $22.68 \%$ \\
8. & $86-91$ & 26 & $13.40 \%$ \\
9. & $92-97$ & 5 & $2.58 \%$ \\
& Total & 194 & $100 \%$ \\
\hline
\end{tabular}


In the Table 3, it is described that students who have SLR score among 44-49 comprising 1 student, 50-55 comprising 1 student, 56-61 comprising 11 students, 62-67 comprising 29 students, 6873 comprising 45 students, $74-79$ comprising 32 students, 80-85 comprising 44 students, $86-91$ comprising 26 students, and 92-97 comprising 5 students.

Based on the frequency distribution Table 3, so the table of SLR classification of students are made as follow (Table 4).

Table 4. SLR Classification of Elementary School Students

\begin{tabular}{cccc}
\hline Score Interval & Criteria & Frequency & Relative Frequency (\%) \\
\hline $84 \leq \mathrm{X}$ & High & 46 & 23.71 \\
$60 \leq \mathrm{X}<83$ & Medium & 142 & 73.20 \\
$\mathrm{X}<59$ & Low & 6 & 3.09 \\
& & 194 & 100 \\
\hline
\end{tabular}

From the Table 4 , it is known that 46 students (23.71\%) possess high SLR, 142 students (73.20\%) possess medium SLR, and 6 students (3.09\%) possess low regulation. Therefore, it can be concluded that, SLR of elementary school students at district of Lendah, Kulon Progo is in the medium category.

Learning Independence

The variable of learning independence in this research was measured using psychological scale. The instrument used to measure students' independency was 26 items, with the score distribution for each item was 1-4. The data of the research result contained mean (M), median (Me), mode (Mo), standard deviation, minimum score, maximum score, and variance. The data are presented in the Table 5 .

Table 5. The Descriptive Analysis of Elementary School Students' learning independence

\begin{tabular}{cc} 
Mean & 73.39 \\
Median & 79.00 \\
Mode & 79 \\
Std. Deviation & 10.260 \\
Variance & 105.265 \\
Mininum & 54 \\
Maximum & 103 \\
\hline
\end{tabular}

From the Table 5, the lowest score was 54; the highest score was 103; the variance was 105,265 ; the standard deviation was 10.260; mode was 79; median was 79.00; and mean was 79.39. The tendency of average mean score of learning independence towards categorization of the ideal average score supposed to be obtained. Therefore, it was obtained the maximum score 103 and the minimum score 54. The calculation of interval class was 8.5497 and rounded to 9 classes with the length of interval was 6 . Therefore, the frequency distribution of students' learning independence can be seen from the Table 6.

Table 6. The Frequency Distribution of Elementary School Students' Learning Independence

\begin{tabular}{cccc}
\hline No. & Interval Skor & Frequency & Percentage $\%$ \\
\hline 1. & $54-59$ & 4 & 2.06 \\
2. & $60-65$ & 13 & 6.70 \\
3. & $66-71$ & 28 & 14.43 \\
4. & $72-77$ & 39 & 20.10 \\
5. & $78-83$ & 42 & 21.65 \\
6. & $84-89$ & 35 & 18.04 \\
7. & $90-95$ & 21 & 10.83 \\
8. & $96-101$ & 11 & 5.67 \\
9. & $102-107$ & 1 & 0.52 \\
& Total & 194 & 100 \\
\hline
\end{tabular}

From the Table 6, it is known that the score of students' learning independence range among 54-59 comprising 4 students, 60-65 comprising 13 students, 66-71 comprising 28 students, $72-77$ comprising 39 students, $78-83$ comprising 42 students, $84-89$ comprising 35 students, $90-95$ comprising 21 
Psychology, Evaluation, and Technology in Educational Research, 2 (2), 2020, 85

Sukowati Sukowati, E. Kus Eddy Sartono, Gunarti Ika Pradewi

students, 96-101 comprising 11 students, and 102-107 comprising 1 student. Furthermore, classification data of students' learning independence is presented in the Table 7.

Table 7. Classification of Elementary School Students' Learning Independence

\begin{tabular}{|c|c|c|c|}
\hline Score Interval & Criteria & Frequency & Percentage $\%$ \\
\hline $85 \leq \mathrm{X}$ & High & 62 & 31.96 \\
\hline $59 \leq X<84$ & Medium & 130 & 67.01 \\
\hline $\mathrm{X}<58$ & Low & 2 & 1.03 \\
\hline \multicolumn{2}{|c|}{ Total } & 194 & 100 \\
\hline
\end{tabular}

Based on Table 7, it is known that there were 62 students $(31.96 \%)$ possessed high learning independence, 130 students (67.01\%) possessed medium learning independence, and 1 student $(1.03 \%)$ possessed low learning independence. Therefore, it can be concluded that the indicator of students' learning independence of grade IV elementary school students is included into medium category.

The Influence of Self-Regulated Learning (SLR) towards Students' Learning Independence

The data analysis in this research used pre-requirement test and hypothesis test. The pre-requirement test in this research used normality test and linearity test. Meanwhile, hypothesis test in this research used t-test, f-test, and determination coefficient test $\left(\mathrm{R}^{2}\right)$.

The normality test used one-sample kolmogorov-smirnov with the aid of SPSS 24 program and it was obtained the result for SLR which was 0.333 and the learning independence which was 0.847 . The significance value (Asym Sig 2 tailed) from the both variables was above 0.05 or $5 \%$ so the distribution of the data from each variable was normal. The summary of normality test was presented in the Table 8 .

Table 8. The Summary of Normality Test

\begin{tabular}{clccc}
\hline No. & \multicolumn{1}{c}{ Variable } & Asymp. Sig (2 tailed) & Significance & Exp. \\
\hline 1. & Selft Regulated Learning (SLR) & 0.333 & 0.05 & Normal \\
2. & Learning Independence & 0.847 & 0.05 & Normal \\
\hline
\end{tabular}

A variable can be stated as having linear relation if the significance value in the reality $<0.05$ and the significance of deviation from linearity $>0.05$. Below is the summary of SLR linearity test towards students' learning independence.

Table 9. Summary of Linearity Test

\begin{tabular}{|c|c|c|c|c|c|}
\hline \multirow{2}{*}{ No. } & \multicolumn{2}{|c|}{ Variable } & \multirow{2}{*}{ Linearity significance } & \multirow{2}{*}{ Sign Deviation from Linearity } & \multirow{2}{*}{ Conclusion } \\
\hline & Dependent & Independent & & & \\
\hline 1. & $\mathrm{X}$ & $\mathrm{Y}$ & 0.000 & 0.448 & Linear \\
\hline
\end{tabular}

In the examination of data of variable $\mathrm{X}$ (SRL) and Y (learning independence), it was obtained the linearity significance less than $0.05(0.0000<0.05)$ so that the data were linear. Furthermore, the hypothesis test was conducted by partially observing the significance of the influence of selfregulation toward the learning independence.

The determination coefficient test (R2) aimed to investigate the best level of accuracy in the regression analysis aimed by the amount of determination coefficients which were 0 (zero) and 1 (one). The result of partial determination coefficient test $\left(\mathrm{r}^{2}\right)$, as follow:

Table 10. The Result of Partial Determination Coefficient Trial (r2)

\begin{tabular}{cc}
\hline Variable & $\mathrm{X}$ \\
\hline Partial Correlation Coefficient & 0.525 \\
$\mathrm{R}^{2}$ & 0.367 \\
$\mathrm{~T}_{\text {count }}$ & 8.516 \\
Significance & 0.0000 \\
\hline
\end{tabular}

The calculation by using SPSS 24 whowed the value of $r 2 x l y x 2$ with $t_{\text {count }} 8.516$ and $t_{\text {table }} 1.972$ and the significance value 0.000 . Significance value $0.000<0.05$ so it was stated as significant. Therefore, it can be concluded that $\mathrm{H}_{0}$ was rejected meaning that there was the influence of SLR toward learning independence. 
Therefore, the result of $F$ test showed the $F_{\text {count }} 240.783$ with the significance $0.000(<0.05)$. With the df numerator which was 2 and df denominator which was 191, so it was obtained $F_{\text {table }} 3.043$. So that, it was stated that SLR significantly influenced students' learning independence.

In the regression test, the value of Constanta was 9.269, meaning that if SLR value is 0 , therefore students' learning independence will be positive that is 9.269. The coefficient of variable regression of SLR, variable $X$ was 0.386 , meaning that if SLR is improved so the learning independence $(\mathrm{Y})$ will be improved (0.386). The coefficient was positive, so there is positive influence between SLR and learning independence where the higher SLR value is, the more students' learning independence found in students.

\section{Discussion}

Self-regulation is pivotal for academic achievement in elementary school and beyond (Duckworth et al., 2019). The result of the first research states that SLR and learning independence are included to medium category. Some indicators of SLR such as the management of emotion, selfinstruction, self-monitoring, self-evaluation, and contingency (Ariani, 2016; McClelland \& Cameron, 2012; Woolfolk, 2007). SLR is one of the important component to improve the learning performance (Cheng, 2011). Gunzenhauser and Saalbach (2020) obtained results that SLR is very important to obtain mathematical competence in elementary schools. SLR in mathematics learning is influenced by affective-motivational components, age, motivation, and gender. While the results of research in Hong Kong self-regulation predict further student motivation. After controlling for previous academic achievement, student motivation was also found to be the strongest indicator in influencing academic achievement. The findings from the study have major implications that motivation and self-regulation as a means of facilitating academic success (Ning \& Downing, 2010).

Meanwhile, the indicator of learning independence consists of the target to be achieved, select the learning source, determine learning source, be independent, can assess themselves in doing the assignments and solving problems (Desmita, 2012; Rusman, 2011). Learning independence occurs because of the support of parents and teachers. The teacher provides support in the form of assignments and provides all facilities for learning. In addition the teacher also provides teaching to students to increase their knowledge (Ziv et al., 2016; Ziv \& Frye, 2004)

The result of second research proves that SLR significantly influence students' learning independence. The increase and decrease of students' learning independence can be influenced by SLR. It is shown by SLR which has $\mathrm{t}_{\text {count }} 8,516$ and has chance of error (p) which is $0.000 \leq 0.05$ meaning that SLR significantly influences students' learning independence. Besides, in the $\mathrm{F}_{\text {test }}$, the result obtained is 240.783 and has chance of error (p) $0.000 \leq 0.05$ meaning that SLR significantly influences students' learning independence. The previous research finding states that students with good SLR causes the high learning independence so that students tend to study better and are able to do supervision, evaluation, and effectively manage their study (Ariani, 2016; Green et al., 2006; Hong \& O’Neil, 2001; Kadhiravan, 2012; Van Laer \& Elen, 2019).

Boekaerts and Corno (2005) said that self-regulation of learning takes place if students direct their own learning. Self-regulatory control can involve thinking, emotions, motivation, behavior and environment. Furthermore, the learning process and results will be evaluated based on criteria or standards set. The process of self-regulation mediates between characteristics and personal and environmental achievements (Pintrich, 2004).

\section{CONCLUSION}

There is a partial significant influence towards students' learning independence. The better the SLR that students possess, the better students' learning indpendence. By the discovered of SLR students, it will help teachers and education authorities to take an action to foster SLR. It also can be studied more deeply in the factors that can affect SLR in students so as to increase student learning independence.

\section{ACKNOWLEDGMENT}

Researcher wants to deliver many thanks to the parties who has helped this research. Many thanks are also presented to Yogyakarta State University for the support, motivation, and suggestion. 
In this occasion, researcher also wants to thank Indonesia Endowment Fund for Education (LPDP) for the financial support to conduct this research.

\section{REFERENCES}

Acar, E., \& Aktamış, H. (2010). The relationship between self-regulation strategies and prospective elementary school teachers' academic achievement in mathematics teaching course. Procedia Social and Behavioral Sciences, 2(2), 5539-5543. https://doi.org/10.1016/j.sbspro.2010.03.903

Aktamış, H., \& Acar, E. (2010). The effect of "laboratory practices in science teaching" course on development of prospective science teachers' self- regulation skills. Procedia - Social and Behavioral Sciences, 2(2), 5549-5553. https://doi.org/10.1016/j.sbspro.2010.03.905

Ariani, D. W. (2016). Why do i study? The mediating effect of motivation and self-regulation on student performance. Business, Management and Education, 14(2), 153-178. https://doi.org/10.3846/bme.2016.329

Arikunto, S. (2010). Prosedur penelitian: Suatu pendekatan praktik. Rineka Cipta.

Artino, A. R., \& Jones, K. D. (2012). Exploring the complex relations between achievement emotions and self-regulated learning behaviors in online learning. The Internet and Higher Education, 15(3), 170-175. https://doi.org/10.1016/j.iheduc.2012.01.006

Azevedo, R., Cromley, J. G., Winters, F. I., Moos, D. C., \& Greene, J. A. (2005). Adaptive human scaffolding facilitates adolescents' self-regulated learning with hypermedia. Instructional Science, 33(5-6), 381-412. https://doi.org/10.1007/s11251-005-1273-8

Bandura, A. (1986). Social foundations of thought and action: A social cognitive theory. Prentice-Hall.

Boekaerts, M. (1997). Self-regulated learning: A new concept embraced by researchers, policy makers, educators, teachers, and students. Learning and Instruction, 7(2), 161-186. https://doi.org/10.1016/S0959-4752(96)00015-1

Boekaerts, M., \& Corno, L. (2005). Self-regulation in the classroom: A perspective on assessment and intervention. Applied Psychology, 54(2), 199-231. https://doi.org/10.1111/j.14640597.2005.00205.x

Butler, D. L. (1998). The strategic content learning approach to promoting self-regulated learning: A report of three studies. Journal of Educational Psychology, 90(4), 682-697. https://doi.org/10.1037/0022-0663.90.4.682

Cheng, C. K. E. (2011). The role of self-regulated learning in enhancing learning performance. The International Journal of Research and Review, 6(1), 1-16.

Creswell, J. W. (2012). Qualitative inquiry and research design: Choosing among five approaches. SAGE Publications.

Creswell, J. W. (2013). Educational research: Planning, conducting, and evaluating quantitative and qualitative research. Pearson.

Davis, D., Chen, G., van der Zee, T., Hauff, C., \& Houben, G.-J. (2016). Retrieval practice and study planning in MOOCs: Exploring classroom-based self-regulated learning strategies at scale. In European conference on technology enhanced learning (pp. 57-71). https://doi.org/10.1007/978-3-319-45153-4_5

De Backer, L., Van Keer, H., \& Valcke, M. (2015). Exploring evolutions in reciprocal peer tutoring groups' socially shared metacognitive regulation and identifying its metacognitive correlates. Learning and Instruction, 38, 63-78. https://doi.org/10.1016/j.learninstruc.2015.04.001

Deci, E. L., \& Ryan, R. M. (2008). Facilitating optimal motivation and psychological well-being across life's domains. Canadian Psychology/Psychologie Canadienne, 49(1), 14-23. https://doi.org/10.1037/0708-5591.49.1.14

Desmita, D. (2012). Psikologi perkembangan peserta didik. Rosdakarya.

Duckworth, A. L., Taxer, J. L., Eskreis-Winkler, L., Galla, B. M., \& Gross, J. J. (2019). Selfcontrol and academic achievement. Annual Review of Psychology, 70(1), 373-399. https://doi.org/10.1146/annurev-psych-010418-103230 
Fonagy, P., \& Target, M. (2002). Early intervention and the development of self-regulation. Psychoanalytic Inquiry, 22(3), 307-335. https://doi.org/10.1080/07351692209348990

Gavora, P., Jakešová, J., \& Kalenda, J. (2015). The Czech validation of the self-regulation questionnaire. Procedia - Social and Behavioral Sciences, 171, 222-230. https://doi.org/10.1016/j.sbspro.2015.01.113

Green, J., Nelson, G., Martin, A. J., \& Marsh, H. (2006). The causal ordering of self-concept and academic motivation and its effect on academic achievement. International Education Journal, 7(4), 534-546.

Gunzenhauser, C., \& Saalbach, H. (2020). Domain-specific self-regulation contributes to concurrent but not later mathematics performance in elementary students. Learning and Individual Differences, 78, 101845. https://doi.org/10.1016/j.lindif.2020.101845

Hong, E., \& O'Neil, H. F. (2001). Construct validation of a trait self-regulation model. International Journal of Psychology, 36(3), 186-194. https://doi.org/10.1080/00207590042000146

Jakešová, J., Gavora, P., Kalenda, J., \& Vávrová, S. (2016). Czech validation of the self-regulation and self-efficacy questionnaires for learning. Procedia - Social and Behavioral Sciences, 217, 313-321. https://doi.org/10.1016/j.sbspro.2016.02.092

Kadhiravan, S. (2012). Self-regulated learning of adolescent in relation to their achievement motivation. Journal of Psychosocial Research, 7(2), 211-218. https://www.questia.com/library/journal/1P3-2957767131/self-regulated-learning-ofadolescents-in-relation

Labuhn, A. S., Bogeholz, S., \& Hasselhorn, M. (2008). Fostering learning through stimulation of selfregulation in science lessons. Zeitschrift Fur Padagogische Psychologie, 22(1), 13-24.

Lai, C., \& Hwang, G. (2016). A self-regulated flipped classroom approach to improving students' learning performance in a mathematics course. Computers \& Education, 100, 126-140. https://doi.org/10.1016/j.compedu.2016.05.006

Maldonado-Mahauad, J., Pérez-Sanagustín, M., Kizilcec, R. F., Morales, N., \& Munoz-Gama, J. (2018). Mining theory-based patterns from Big data: Identifying self-regulated learning strategies in Massive Open Online Courses. Computers in Human Behavior, 80, 179-196. https://doi.org/10.1016/j.chb.2017.11.011

McClelland, M. M., \& Cameron, C. E. (2012). Self-regulation in early childhood: Improving conceptual clarity and developing ecologically valid measures. Child Development Perspectives, 6(2), 136-142. https://doi.org/10.1111/j.1750-8606.2011.00191.x

Mudjiman, H. (2007). Belajar mandiri (Self-motivated learning). UNS Press.

Ning, H. K., \& Downing, K. (2010). The reciprocal relationship between motivation and selfregulation: A longitudinal study on academic performance. Learning and Individual Differences, 20(6), 682-686. https://doi.org/10.1016/j.lindif.2010.09.010

Panadero, E. (2017). A review of self-regulated learning: Six models and four directions for research. Frontiers in Psychology, 8(422), 1-28. https://doi.org/10.3389/fpsyg.2017.00422

Panadero, E., \& Järvelä, S. (2015). Socially shared regulation of learning: A review. European Psychologist, 20(3), 190-203. https://doi.org/10.1027/1016-9040/a000226

Peeters, J., De Backer, F., Kindekens, A., Triquet, K., \& Lombaerts, K. (2016). Teacher differences in promoting students' self-regulated learning: Exploring the role of student characteristics. Learning and Individual Differences, 52, 88-96. https://doi.org/10.1016/j.lindif.2016.10.014

Pintrich, P. R. (2004). A conceptual framework for assessing motivation and self-regulated learning in college students. Educational Psychology Review, 16(4), 385-407. https://doi.org/10.1007/s10648-004-0006-x

Rusman, R. (2011). Model-model pembelajaran: Mengembangkan profesionalisme guru. Rajawali Pers.

Ryan, R. M., \& Deci, E. L. (2017). Self-determination theory: Basic psychological needs in motivation, development, and wellness. Guilford Press. 
Schreiber, J. B., \& Asner-Self, K. (2010). Educational research. Wiley Global Education.

Schunk, D. H. (2005). Commentary on self-regulation in school contexts. Learning and Instruction, 15(2), 173-177. https://doi.org/10.1016/j.learninstruc.2005.04.013

Schunk, D. H. (2012). Learning theories: An educational perspective. Pearson.

Stefanou, C., Lord, S. M., Prince, M. J., \& Chen, J. C. (2014). Effect of classroom gender composition on students' development of self-regulated learning competencies. International Journal of Engineering Education, 30(2), 333-342. http://www.ijee.ie/latestissues/Vol302/10_ijee2832ns.pdf

Van Laer, S., \& Elen, J. (2019). The effect of cues for calibration on learners' self-regulated learning through changes in learners' learning behaviour and outcomes. Computers \& Education, 135, 30-48. https://doi.org/10.1016/j.compedu.2019.02.016

Vandevelde, S., Van Keer, H., \& Rosseel, Y. (2013). Measuring the complexity of upper primary school children's self-regulated learning: A multi-component approach. Contemporary Educational Psychology, 38(4), 407-425. https://doi.org/10.1016/j.cedpsych.2013.09.002

Vermunt, J. D., \& Vermetten, Y. J. (2004). Patterns in student learning: relationships between learning strategies, conceptions of learning, and learning orientations. Educational Psychology Review, 16(4), 359-384. https://doi.org/10.1007/s10648-004-0005-y

Wong, J., Khalil, M., Baars, M., de Koning, B. B., \& Paas, F. (2019). Exploring sequences of learner activities in relation to self-regulated learning in a massive open online course. Computers \& Education, 140(June), 103595. https://doi.org/10.1016/j.compedu.2019.103595

Woolfolk, A. (2007). Educational psychology. Pearson Education, Inc.

Zheng, J., Xing, W., Zhu, G., Chen, G., Zhao, H., \& Xie, C. (2020). Profiling self-regulation behaviors in STEM learning of engineering design. Computers \& Education, 143, 103669. https://doi.org/10.1016/j.compedu.2019.103669

Zimmerman, B. J. (1990). Self-regulated learning and academic achievement: An overview. Educational Psychologist, 25(1), 3-17. https://doi.org/10.1207/s15326985ep2501_2

Zimmerman, B. J. (2008). Investigating self-regulation and motivation: Historical background, methodological developments, and future prospects. American Educational Research Journal, 45(1), 166-183. https://doi.org/10.3102/0002831207312909

Zimmerman, B. J., \& Martinez-Pons, M. (1990). Student differences in self-regulated learning: Relating grade, sex, and giftedness to self-efficacy and strategy use. Journal of Educational Psychology, 82(1), 51-59. https://doi.org/10.1037/0022-0663.82.1.51

Ziv, M., \& Frye, D. (2004). Children's understanding of teaching: the role of knowledge and belief. Cognitive Development, 19(4), 457-477. https://doi.org/10.1016/j.cogdev.2004.09.002

Ziv, M., Solomon, A., Strauss, S., \& Frye, D. (2016). Relations between the development of teaching and theory of mind in early childhood. Journal of Cognition and Development, 17(2), 264-284. https://doi.org/10.1080/15248372.2015.1048862 